Chapter 13

\title{
Acupuncture for Cancer Patients: Practice and Research
}

\author{
Lizhen Wang and Ting Bao \\ Additional information is available at the end of the chapter \\ http://dx.doi.org/10.5772/54005
}

\section{Introduction}

Acupuncture is a traditional Chinese medicine technique that involves inserting and manipulating filiform needles in predefined points on the skin (i.e., acupuncture points) to achieve therapeutic effect. Although studies have not been able to fully explain the mechanism of acupuncture, it has been proposed that acupuncture worked through its effect on neurotransmitters and neurohormones. [1, 2]

Acupuncture points can be stimulated in various ways. With manual acupuncture, the filiform acupuncture needle is inserted in an acupuncture point and manually rotated to stimulate the point. With electroacupuncture, acupuncture points are stimulated by passing electrical current through inserted needles. Electrical current may also be passed through an electrode on the skin without inserting acupuncture needles, a technique called noninvasive electrostimulation. Acupressure is a form of modified acupuncture that replaces needles with physical pressure generated with either a finger or device such as an embedded stud in an elastic wrist band.

Acupuncture and acupuncture point stimulation have been widely used as a complementary therapy to treat wide range of illnesses by many patients, especially cancer patients. Growing evidence suggests that acupuncture is beneficial for cancer pain, chemotherapy-induced nausea, vomiting, and may be beneficial for symptoms such as radiation therapy-induced xerostomia, fatigue, hot flashes, depression, anxiety, and insomnia. This chapter provides an overview of the role of acupuncture in alleviating cancer patients' symptoms, with focus on the scientific evidence behind the practice. 


\section{Acupuncture to treat cancer pain}

Cancer pain is the most common and one of the most distressing and feared symptoms among cancer patients. It is estimated that up to two thirds of patients with metastatic cancer suffered from cancer related pain.[3] More than 75\% of hospitalized oncology patients experienced cancer related pain.[4-6] Due to its importance, pain is often referred to as the fifth vital sign of oncology patients. Cancer pain varies both by types of malignancy, and sites of cancer involvement.[7] The majority of cancer pain is caused by direct effect of cancer as a result of visceral involvement, bony metastasis, soft tissue invasion, or infiltration to the nerve or nerve plexus.[8] Cancer treatments such as chemotherapy, radiation and surgery may also cause treatment-induced cancer pain.

Cancer pain has traditionally been treated with opioids and interventional anesthetic or neurosurgical procedures. Despite maximal use of pain medications and application of interventional procedures, a significant portion of cancer patients still suffer from pain. In addition, the undesired side effects of long term usage of opioid pain medication, particularly change of mental status, constipation, nausea, fear of dependence, could be an issue. As a result, cancer patients often seek help in complementary alternative medicine, including acupuncture in an attempt to control their pain.

Even though acupuncture has been widely used among oncology patients to control cancer pain, the role of acupuncture in controlling cancer pain has not been clearly established through well-designed clinical trials. Many clinical trials suffered from methodological flaws such as poor study design, small sample size and lack of statistical analysis.[11] As a result, two recent Cochrane systematic reviews of randomized controlled clinical trials on the role of acupuncture to treat cancer pain showed no strong evidence for the effectiveness of acupuncture in reducing cancer pain. Another Cochrane systematic review assessed the value of Transcutaneous Electrical Nerve Stimulation (TENS) in the management of cancerrelated pain in adults and remained inconclusive due to lack of suitable RCTs.[14]

On the other hand, a number of recent well-designed Randomized Controlled Trials (RCTs) have been conducted to study the role of acupuncture in treating cancer pain and are summarized in table 1.[15-23] Among them, four RCTs studied the efficacy of different types of acupuncture in controlling postoperative pain and presented mixed results. Deng et al's RCT on 106 cancer patients experiencing post-thoracotomy pain showed no statistical difference between the real versus sham acupuncture groups in patient's pain scores measured by Brief Pain Inventory at the 30-, 60-, and 90 days follow-ups.[15] The efficacy of the unique intradermal needles used in this study was questionable. Wong et al's smaller RCT ( $N=27)$ showed a trend of lower Visual Analog Scale (VAS) pain scores in patients receiving electroacupuncture when compared to patients receiving sham acupuncture on post-operative days 2 and 6; and a statistically significant lower cumulative dose of Patient Controlled Analgesia (PCA) on postop day 2 ( $p<0.05)$.[16] This study was, however, limited by its small sample size. Mehling et al's RCT ( $N=93)$ compared acupuncture plus massage therapy with usual care in controlling postoperative pain, nausea, vomiting and depressive moods.[17] It showed that postop acupuncture and massage in addition to usual care significantly im- 
proved pain control when compared to usual care alone. Lastly, Pfister et al's study showed that four weekly acupuncture treatments significantly reduced pain and improved function in cancer patients with chronic pain or dysfunction due to neck dissection than standard care alone.[24] However, with no sham therapy group in the last two studies, it is difficult to tease out the placebo effect, and leave the question that if the professionally trained acupuncturists and massage therapists and real acupuncture needles are required in the intervention remained unanswered.

\begin{tabular}{|c|c|c|c|c|c|}
\hline $\begin{array}{l}\text { Reference/ } \\
\text { Sample size }\end{array}$ & Type of Pain & $\begin{array}{l}\text { Treatment } \\
\text { Groups }\end{array}$ & $\begin{array}{c}\text { Treatment } \\
\text { Duration }\end{array}$ & $\begin{array}{l}\text { Evaluation } \\
\text { Method }\end{array}$ & Results \\
\hline $\begin{array}{l}\text { Deng et al } \\
2008[15] \\
N=106\end{array}$ & $\begin{array}{l}\text { Post- } \\
\text { thoracotomy } \\
\text { pain }\end{array}$ & $\begin{array}{c}\text { Group 1: } \\
\text { intradermal } \\
\text { acupuncture; } \\
\text { 2: sham } \\
\text { acupuncture }\end{array}$ & 1 month & $\begin{array}{l}\text { Brief pain } \\
\text { inventory }\end{array}$ & $\begin{array}{l}\text { No difference between the two } \\
\text { groups }\end{array}$ \\
\hline $\begin{array}{c}\text { Wong et al } \\
\begin{array}{c}2006[16] \\
N=27\end{array}\end{array}$ & $\begin{array}{l}\text { Post- } \\
\text { thoracotomy } \\
\text { pain }\end{array}$ & $\begin{array}{l}\text { Group1:electroac } \\
\text { upuncture, } \\
\text { 2: sham } \\
\text { acupuncture }\end{array}$ & 7 days & $\begin{array}{c}\text { VAS and } \\
\text { medication } \\
\text { quantification }\end{array}$ & $\begin{array}{c}\text { Lower cumulative dose of patient } \\
\text { controlled analgesic morphine used } \\
\text { on postop day } 2 \text { in EA group }(P< \\
0.05)\end{array}$ \\
\hline $\begin{array}{c}\text { Mehling et } \\
\text { al 2007[17] } \\
\mathrm{N}=45\end{array}$ & Post-op pain & $\begin{array}{c}\text { Group 1: } \\
\text { acupuncture and } \\
\text { massage; } \\
\text { 2: usual care }\end{array}$ & 2 days & $\begin{array}{l}\text { Pain numeric } \\
\text { rating scale }\end{array}$ & $\begin{array}{l}\text { The treatment group has less pain } \mathrm{P} \\
\qquad=0.038\end{array}$ \\
\hline $\begin{array}{c}\text { Pfister et al } \\
\text { 2010[24] } \\
\text { N=58 }\end{array}$ & $\begin{array}{c}\text { pain and } \\
\text { dysfunction in } \\
\text { patients with } \\
\text { cancer with a } \\
\text { history of neck } \\
\text { dissection }\end{array}$ & $\begin{array}{l}\text { 1.acupuncture } \\
\qquad(\mathrm{N}=28) \\
\text { 2. usual care } \\
(\mathrm{N}=30)\end{array}$ & $\begin{array}{l}\text { Weekly for } 4 \\
\text { weeks }\end{array}$ & $\begin{array}{c}\text { Constant- } \\
\text { Murley score, a } \\
\text { composite } \\
\text { measure of } \\
\text { pain, function, } \\
\text { and activities of } \\
\text { daily living }\end{array}$ & $\begin{array}{l}\text { Constant-Murley scores improved } \\
\text { more in the acupuncture group } \\
\text { (adjusted difference between groups } \\
=11.2 ; 95 \% \mathrm{Cl}, 3.0 \text { to } 19.3 ; \mathrm{P}=.008 \text { ). }\end{array}$ \\
\hline $\begin{array}{l}\text { Alimi et al } \\
\text { 2003[19] } \\
\mathrm{N}=90\end{array}$ & $\begin{array}{l}\text { Peripheral or } \\
\text { central } \\
\text { neuropathic } \\
\text { pain arising } \\
\text { after cancer } \\
\text { treatment }\end{array}$ & $\begin{array}{l}\text { Group 1: } \\
\text { auricular } \\
\text { acupuncture; } \\
\text { 2: sham control; } \\
\text { 3: control }\end{array}$ & 2 month & VAS & $\begin{array}{l}\text { The acupuncture group had a } \\
\text { significant decrease }(P<0.01) \text { in pain } \\
\text { intensity after } 2 \text { months ( } 35 \% \\
\text { decrease) compared with the control } \\
\text { groups }\end{array}$ \\
\hline $\begin{array}{l}\text { Dang et al } \\
1998[22] \\
N=48\end{array}$ & $\begin{array}{c}\text { Stomach } \\
\text { Cancer Pain }\end{array}$ & $\begin{array}{c}\text { Group 1: } \\
\text { acupuncture; } \\
\text { 2:acupuncture } \\
\text { point injection; } \\
\text { 3: western } \\
\text { analgesics }\end{array}$ & 2 months & WHO pain scale & $\begin{array}{l}\text { No difference among the three } \\
\text { groups in long-term effective rate of } \\
\text { analgesia, } 81 \% \text { in all groups. }\end{array}$ \\
\hline
\end{tabular}




\begin{tabular}{|c|c|c|c|c|c|}
\hline $\begin{array}{l}\text { Reference/ } \\
\text { Sample size }\end{array}$ & & $\begin{array}{c}\text { Treatment } \\
\text { Groups }\end{array}$ & $\begin{array}{l}\text { Treatment } \\
\text { Duration }\end{array}$ & $\begin{array}{l}\text { Evaluation } \\
\text { Method }\end{array}$ & ts \\
\hline $\begin{array}{c}\text { He et al } \\
1999[21] \\
N=80\end{array}$ & $\begin{array}{l}\text { Post-operative } \\
\text { pain in breast } \\
\text { cancer } \\
\text { patients }\end{array}$ & $\begin{array}{c}\text { Group 1: } \\
\text { acupuncture; } \\
\text { 2: usual care }\end{array}$ & $\begin{array}{l}\text { Post-op days } \\
3,5,7 \text { and day } \\
\text { of discharge }\end{array}$ & $\begin{array}{l}\text { VAS and range } \\
\text { of movement }\end{array}$ & $\begin{array}{l}\text { The acupuncture group had an } \\
\text { improved post-op pain }(p \leq 0.01) \text { and } \\
\text { range of movement }(p<0.001)\end{array}$ \\
\hline $\begin{array}{l}\text { Crew et al } \\
2010[27] \\
N=38\end{array}$ & $\begin{array}{c}\text { Aromatase } \\
\text { inhibitor- } \\
\text { induced joint } \\
\text { muscle pain }\end{array}$ & $\begin{array}{c}\text { Group 1: } \\
\text { acupuncture } \\
\text { 2: sham } \\
\text { acupuncture }\end{array}$ & $\begin{array}{l}\text { Twice per } \\
\text { week for } 6 \\
\text { weeks }\end{array}$ & $\begin{array}{c}\text { Brief Pain } \\
\text { Inventory-Short } \\
\text { Form (BPI-SF) }\end{array}$ & $\begin{array}{c}\text { Significantly less pain }(p=0.003) \text { and } \\
\text { pain-related interference }(p=0.002) \\
\text { at week } 6 \text { in acupuncture arm than } \\
\text { sham acupuncture arm }\end{array}$ \\
\hline
\end{tabular}

Table 1. Summary of Randomized Control Trials on Acupuncture for Cancer Pain Relief

There have been a number of clinical trials showing the effect of acupuncture in reducing neuropathic pain in cancer patients. Among them, one clinical trial showed the effectiveness of auricular acupuncture in treating cancer treatment induced neuropathy.[19] This was a randomized, blinded, controlled trial conducted on 90 cancer patients with peripheral or central neuropathic pain arising after cancer treatment. The patients were randomized into one of three arms. One arm received real auricular acupuncture at real ear acupuncture points, which is defined as points where the electrodermal signal is being detected. The other two arms were placebo arms. The second arm received real auricular acupuncture at the placebo points. The third arm received sham acupuncture through auricular seeds at the placebo points.[19] All patients received two courses of real or placebo auricular acupuncture in two months, one month apart. The needles were left in place until they fell out or were removed at a follow up appointment. Their pain intensity measured by VAS at the end of the second month was used to measure the treatment efficacy. This study showed that in the group that received real acupuncture, pain intensity decreased by $36 \%$ at the end of 2 months when compared with baseline, whereas it only decreased by $2 \%$ in the placebo groups $(\mathrm{P}<0.0001)$. [19 A recent acupuncture versus best medical care to treat peripheral neuropathy study showed that $76 \%$ patients in the acupuncture group had improvement in symptoms and nerve conduction studies whereas only $15 \%$ in the best medical care group did.[26] In addition, this study showed full correlation between the improvement in symptoms and nerve conduction studies.[26] Lastly, a recent randomized controlled clinical trial demonstrated that acupuncture significantly reduced aromatase inhibitor-associated joint pain and stiffness than sham acupuncture.[27]

These studies suggest that acupuncture may be a valuable alternative modality within a comprehensive program of cancer pain management. With minimal side effects reported, acupuncture remains a viable option for patients suffering from cancer pain. Further research should focus on using rigorous scientific methodology and an effective protocol based on a sound, evidence-based rationale. 


\section{Acupuncture to treat cancer therapy induced nausea and vomiting}

Chemotherapy-Induced Nausea and Vomiting (CINV) is one of the most common and feared treatment-related side effects among patients with cancer. As a result, nutritional status, quality of life, and treatment adherence may be severely compromised in patients.[28] Over the past 20 years, better understanding of the physiology of CINV and the subsequent development of modern pharmacologic antiemetic agents have substantially improved the control of CINV. However, study suggests that CINV remains a significant problem among these patients.[29]

CINV can either be acute, delayed, or anticipatory. Acute CINV occurs within 24 hours of chemotherapy, usually beginning within 2 to 4 hours and peaking in the first 4 to 6 hours. [30] Delayed CINV occurs from day 2 to 6 of chemotherapy.[30] Anticipatory CINV occurs before chemotherapy treatments in patients who have previously experienced significant CINV.[30] Most antiemetic research focuses on reducing acute and delayed CINV, with the understanding that this would result in better control of anticipatory CINV. Despite recent advances in pharmacologic antiemetic therapy, additional treatment for breakthrough CINV is needed. Several randomized controlled clinical trials suggested the efficacy of acupuncture in controlling this side effect.

A meta-analysis of 11 RCTs on 1247 cancer patients with CINV showed that the proportion of acute vomiting episodes was significantly lower in the acupuncture point stimulation group than the control group ( $22 \%$ vs. $31 \%$, p=0.04). Those trials, however, did not show that acupuncture significantly alleviate acute chemotherapy-induced nausea or delayed CINV. $[35,36]$ The clinical relevance of these results were limited by the fact that those clinical trials predated the use of aprepitant and that only 1 or 2 acupuncture points were stimulated during acupuncture treatment. More clinical trials to study the effect of acupuncture with additional antiemetic acupuncture points in adjunct to modern pharmacologic antiemetic therapy are needed.

In addition to acupuncture, acupressure has been demonstrated to effectively reduce CINV. In a single-arm prospective study on 100 metastatic solid tumor patients experiencing persistent CINV despite standard antiemetic agents, $68 \%$ of patients' emetic symptoms improved after being treated with acupressure at PC6 point.[33] A RCT on 160 breast cancer patients who experienced moderate nausea during previous chemotherapy cycles and were getting ready to begin their $2^{\text {nd }}$ or $3^{\text {rd }}$ cycle of chemotherapy showed that acupressure at PC6 through a wrist device significantly decreased the amount of delayed vomiting and the intensity of nausea over time when compared with placebo acupressure and usual care groups.[34] The authors concluded that acupressure was safe and effective for cancer patients to manage delayed CINV and should be offered to breast cancer patients during chemotherapy. [34]

There has been a number of RCTs studying the effect of acupuncture in reducing RadiationInduced Nausea and Vomiting (RINV), and showed that even though there is no statistically significant difference between real and sham acupuncture, both treatments were significant- 
ly more effective than standard care alone in reducing the frequency and severity of RINV (table 2). Over $90 \%$ patients in both treatment groups believed that acupuncture has been effective against radiation-induced nausea.[35]

\begin{tabular}{|c|c|c|c|c|}
\hline $\begin{array}{l}\text { Reference/ } \\
\text { Sample size }\end{array}$ & Treatment Groups & $\begin{array}{c}\text { Treatment } \\
\text { Duration }\end{array}$ & $\begin{array}{c}\text { Primary end } \\
\text { point }\end{array}$ & Results \\
\hline $\begin{array}{c}\text { Enblom et al } \\
\begin{array}{c}2012[35] \\
N=215\end{array}\end{array}$ & $\begin{array}{l}\text { 1. verum acupuncture } \\
\text { (penetrating and causing } \\
\text { 'deqi' sensation) ( } n=109 \text { ) } \\
\text { 2. sham acupuncture (use } \\
\text { non-penetrating sham } \\
\text { needles) }(n=106)\end{array}$ & $\begin{array}{l}\text { two to three } \\
\text { times per } \\
\text { week during } \\
\text { radiation }\end{array}$ & $\begin{array}{l}\% \text { of patients } \\
\text { with at least } 1 \\
\text { emesis episode } \\
\text { during } \\
\text { radiation }\end{array}$ & $\begin{array}{l}70 \% \text { patients in the verum acupuncture } \\
\text { group and } 62 \% \text { in the sham } \\
\text { acupuncture group experienced nausea } \\
\text { at least } 1 \text { emesis during radiation. } \\
\text { No significant difference between two } \\
\text { groups. }\end{array}$ \\
\hline $\begin{array}{c}\text { Enblom et al } \\
\begin{array}{c}2011[36] \\
N=262\end{array}\end{array}$ & $\begin{array}{l}\text { 1.verum acupuncture } \\
\text { ( } n=109 ; 99 \text { provided data) } \\
\text { 2. sham acupuncture } \\
\text { ( } n=106 ; 101 \text { provided data) } \\
\text { 3. standard care alone } \\
\text { ( } n=62 ; 62 \text { provided data) }\end{array}$ & $\begin{array}{c}\text { 2-3 times per } \\
\text { week during } \\
\text { radiation }\end{array}$ & $\begin{array}{l}\text { Occurrence of } \\
\text { nausea and } \\
\text { emesis in each } \\
\text { group was after } \\
\text { a mean dose of } \\
27 \text { Gray. }\end{array}$ & $\begin{array}{l}\text { Verum group: } 37 \% \text { experienced nausea, } \\
\qquad 8 \% \text { vomiting; } \\
\text { Sham group: } 37 \% \text { experienced nausea, } \\
\text { 7\% vomiting; } \\
\text { Standard care group: } 65 \% \text { experienced } \\
\text { nausea, } 15 \% \text { vomiting. }\end{array}$ \\
\hline
\end{tabular}

Table 2. Summary of Randomized Control Trials on Acupuncture for the Relief of radiation induced nausea and vomiting

These studies suggest that acupuncture and acupressure are effective in reducing cancer treatment-induced nausea and vomiting in cancer patients. Most studies were conducted on break through CINV after the patients failed conventional anti-emetic medication. Further research needs to be conducted to determine if the combination of antiemetics and P6 acupoint stimulation works better than each component alone. Indeed, an animal study showed that combination therapy of electroacupuncture (EA) at P6 acupoint with ondansetron, droperidol or metoclopramide prevented emesis more significantly than EA or any of the medications alone.[37] These data suggested that EA and anti-emetic medication work synergistically.

\section{Acupuncture to treat cancer fatigue}

Fatigue is a common symptom in patients with cancer and a frequent side effect of chemo and radiation therapy, with no effective treatment exists. Several prospective pilot studies have suggested that acupuncture may benefit patients suffering from cancer fatigue (table 3). These studies were limited by their small sample size, but have provided encouraging information for further lare sample sized RCTs. 


\begin{tabular}{|c|c|c|c|c|}
\hline $\begin{array}{l}\text { Reference/ } \\
\text { Sample size }\end{array}$ & Treatment Groups & Treatment & $\begin{array}{l}\text { Evaluation } \\
\text { Method }\end{array}$ & Results \\
\hline $\begin{array}{l}\text { Molassiotis } \\
\text { et al } \\
200738 \\
(\mathrm{~N}=47)\end{array}$ & $\begin{array}{l}\text { 1.acupuncture: six 20-min } \\
\text { sessions over } 2 \text { week } \\
\text { 2.acupressure: massage } \\
\text { acupoints daily } \\
\text { 3.sham acupressure: } \\
\text { massage none acupoints } \\
\text { daily }\end{array}$ & Two weeks & $\begin{array}{l}\text { Multidimensiona } \\
\text { I Fatigue } \\
\text { Inventory }\end{array}$ & $\begin{array}{l}\text { Both acupuncture and acupressure } \\
\text { significantly reduced cancer fatigue. } \\
\text { Acupuncture was a more effective } \\
\text { method than acupressure or sham } \\
\text { acupressure. }\end{array}$ \\
\hline $\begin{array}{l}\text { Johnston et } \\
\text { al. } \\
2011[68] \\
(\mathrm{N}=50)\end{array}$ & $\begin{array}{l}\text { 1. education integrated } \\
\text { with acupuncture } \\
\text { 2. usual care }\end{array}$ & $\begin{array}{l}\text { improve self- } \\
\text { care + weekly } \\
\text { 50-minute } \\
\text { acupuncture } \\
\text { sessions }\end{array}$ & $\begin{array}{l}\text { Brief Fatigue } \\
\text { Inventory (BFI) }\end{array}$ & $\begin{array}{l}\text { A 2.38-point decline in fatigue as } \\
\text { measured by the BFI when compared to } \\
\text { usual care control ( } 90 \% \text { Confidence } \\
\text { Interval from } 0.586 \text { to } 5.014 ; p<0.10 \text { ). }\end{array}$ \\
\hline $\begin{array}{l}\text { Balk et al. } \\
2009[69] \\
(\mathrm{N}=23)\end{array}$ & $\begin{array}{l}\text { 1.real acupuncture } \\
\text { 2.sham acupuncture }\end{array}$ & $\begin{array}{l}\text { once to twice } \\
\text { per week } \\
\text { during the 6- } \\
\text { week course of } \\
\text { radiation } \\
\text { therapy }\end{array}$ & $\begin{array}{l}\text { Functional } \\
\text { Assessment of } \\
\text { Chronic Illness } \\
\text { Therapy-Fatigue } \\
\text { Subscale }\end{array}$ & $\begin{array}{l}\text { Both groups had improvement in } \\
\text { fatigue, fatigue distress, quality of life } \\
\text { and depression from baseline to week } \\
\text { 10, but no statistically significant } \\
\text { intergroup difference. }\end{array}$ \\
\hline $\begin{array}{l}\text { Mao et al. } \\
2009[39] \\
(\mathrm{N}=16)\end{array}$ & $\begin{array}{l}\text { 1. acupuncture: } 12 \\
\text { treatments }\end{array}$ & $\begin{array}{l}12 \text { treatments } \\
\text { during the } \\
\text { course of } \\
\text { radiation } \\
\text { therapy }\end{array}$ & $\begin{array}{l}\text { The Lee Fatigue } \\
\text { Scale (LFS), the } \\
\text { Patient Global } \\
\text { Impression of } \\
\text { Change (PGIC). }\end{array}$ & $\begin{array}{l}\text { Average fatigue and energy domains of } \\
\text { the LFS remained stable during and after } \\
\text { RT, without any expected statistical } \\
\text { decline owing to RT. }\end{array}$ \\
\hline
\end{tabular}

Table 3. Summary of Pilot Studies on Acupuncture for Cancer Fatigue

Among these pilot studies, Molassiotis et al's pilot three-arm RCT was the most telling. In this trial, 47 cancer patients experiencing moderate to severe cancer fatigue were randomized into three groups: acupuncture $(\mathrm{n}=15)$, acupressure $(\mathrm{n}=16)$, and sham acupressure (n $=16$ ). Patients in the acupuncture group received six 20-minute acupuncture sessions over two weeks, whereas patients in the two acupressure groups were taught to massage real versus sham acupuncture points daily for two weeks. [38] The Multidimensional Fatigue Inventory was used to assess their responses at baseline, week 2 and week 4 follow up. At the end of week two, general fatigue, physical fatigue, activity, and motivation significantly improved in the acupuncture and acupressure groups when compared to baseline.[38] At the end of week 2, fatigue level improved by $36 \%$ in the acupuncture group, $19 \%$ in the acupressure group and $0.6 \%$ in the control group. Moreover, the improvement maintained at the week 4 follow-up.[38] Acupuncture was found to be a more effective method than acupressure or sham acupressure. The authors concluded that acupuncture showed great potential 
to manage cancer-related fatigue and should be tested further with larger sample size and multi-center RCT. [38]

In addition to treating cancer fatigue, pilot study has also suggested the effect of acupuncture in preventing radiation-induced fatigue. A single-arm acupuncture trial conducted on 16 cancer patients undergoing radiation showed that 12 acupuncture treatment during radiation resulted in a stable average fatigue score during radiation therapy and $87 \%$ patients reported either stable or improved fatigue during radiation. [39] These findings invite further research to study the role of acupuncture in preventing the development of cancer fatigue.

These pilot clinical trials encourages further large sample sized randomized controlled trials to evaluate the effect of acupuncture on treating and preventing fatigue in cancer patients.

\section{Acupuncture to treat hot flashes in cancer patients}

Vasomotor symptoms (hot flashes, night sweats) are common complaints among breast cancer survivors. These symptoms are usually the result of breast cancer related treatment such as chemotherapy-induced menopause or estrogen deprivation therapy. Management of hot flashes among breast cancer survivors is challenging as the most effective treatment, hormone replacement therapy, is associated with increased risk of breast cancer recurrence and development of new breast cancer. Acupuncture shows promise as a therapeutic approach for hot flashed with minimal side effects. The role of acupuncture in reducing hot flashes in women with breast cancer has been studied in a number of well-designed RCTs (table 4).

In 2007, Deng et al reported results from a randomized, sham-controlled trial on the effect of acupuncture in treating breast cancer patients who experienced three or more hot flashes per day.[40] Seventy-two women were randomized to 8 sessions (4 weeks biweekly) real versus sham acupuncture. The primary end point was hot flash frequency at week 6 . Patients randomized to the sham acupuncture arm were crossed over to receive real acupuncture at week 7 and were evaluated 6 weeks later. All patients were also evaluated at 6 months. The investigators reported that the mean number of hot flashes per day at week 6 changed from 8.7 to 6.2 in the real acupuncture arm, and from 10.0 to 7.6 in the sham acupuncture arm. The difference between real and sham acupuncture arm was not statistically significant $(p=0.3)$. When patients in the sham acupuncture arm were crossed over to receive real acupuncture, their hot flash frequency further reduced from 7.6 to 5.8. The reduction in hot flashes in all patients persisted during the 6 months follow up (real acupuncture arm down to 6.1 per day and sham acupuncture arm to 6.8 per day). The authors concluded that acupuncture reduced hot flash frequency as it was reduced significantly in both treatment arms, even though there was no statistically significant difference between real versus sham acupuncture.[40] Importantly, only fourteen minor adverse events, such as mild bleeding and bruising that did not require medical intervention were reported from the 560 acupuncture sessions.[40] Similar results were demonstrated in other RCT studying the effect of acupuncture to treat hot flashes in perimenopausal women.[41] 


\begin{tabular}{|c|c|c|c|c|}
\hline $\begin{array}{l}\text { Reference/ } \\
\text { Sample size }\end{array}$ & Treatment Groups & $\begin{array}{l}\text { Treatment } \\
\text { Duration }\end{array}$ & $\begin{array}{l}\text { Evaluation } \\
\text { Method }\end{array}$ & Results \\
\hline $\begin{array}{l}\text { Deng et al. } \\
2007[40] \\
(\mathrm{N}=72)\end{array}$ & $\begin{array}{l}\text { 1. real acupuncture } \\
\text { 2. sham acupuncture }\end{array}$ & 4 weeks & $\begin{array}{l}\text { Hot flash } \\
\text { frequency }\end{array}$ & $\begin{array}{l}\text { True acupuncture was associated with } \\
0.8 \text { fewer hot flashes per day than sham } \\
\text { at } 6 \text { weeks, but the difference did not } \\
\text { reach statistical significance }\end{array}$ \\
\hline $\begin{array}{l}\text { Hervik et al. } \\
2009[42] \\
(\mathrm{N}=59)\end{array}$ & $\begin{array}{l}\text { 1. real acupuncture } \\
\text { 2. sham acupuncture }(S A)\end{array}$ & 10 weeks & $\begin{array}{l}\text { Mean number of } \\
\text { hot flashes at } \\
\text { day and night, } \\
\text { and Kupperman } \\
\text { index. }\end{array}$ & $\begin{array}{l}\text { During the treatment period mean } \\
\text { number of hot flashes at day and night } \\
\text { was significantly reduced by almost } \\
60 \% \text {, respectively from baseline in the } \\
\text { acupuncture group, and was further } \\
\text { reduced by } 30 \% \text { both at day and night } \\
\text { during the next } 12 \text { weeks. Kupperman } \\
\text { index was reduced by } 44 \% \text { from baseline } \\
\text { to the end of the treatment period in the } \\
\text { acupuncture group, and largely } \\
\text { maintained } 12 \text { weeks after treatment } \\
\text { ended. }\end{array}$ \\
\hline $\begin{array}{l}\text { Frisk et al. } \\
2008[43] \\
(\mathrm{N}=45)\end{array}$ & $\begin{array}{l}\text { 1. electro-acupuncture } \\
\qquad(\mathrm{EA}) \\
\text { 2.hormone therapy }(\mathrm{HT})\end{array}$ & 24 months & $\begin{array}{l}\text { Number of hot } \\
\text { flashes per day }\end{array}$ & $\begin{array}{l}\text { In the EA group, the median number of } \\
\text { hot flushes } / 24 \text { h decreased from } 9.6 \text { at } \\
\text { baseline to } 4.3 \text { at } 12 \text { weeks of treatment } \\
\text { ( } p<0.001) \text {. In the HT group, the median } \\
\text { number of hot flushes } / 24 \text { h decreased } \\
\text { from } 6.6 \text { at baseline to } 0 .\end{array}$ \\
\hline $\begin{array}{l}\text { Walker et al. } \\
2010[44] \\
(\mathrm{N}=50)\end{array}$ & $\begin{array}{l}\text { 1. acupuncture } \\
\text { 2. venlafaxine }\end{array}$ & 12 weeks & $\begin{array}{l}\text { Hot flashes } \\
\text { frequency and } \\
\text { severity }\end{array}$ & $\begin{array}{c}\text { acupuncture was as effective as } \\
\text { venlafaxine }\end{array}$ \\
\hline
\end{tabular}

Table 4. Summary of Randomized Control Trials on Acupuncture for hot flashes in breast cancer patients

In 2008, Hervik et al reported another randomized, sham acupuncture-controlled trial on the effect of acupuncture in treating breast cancer patients suffering from hot flashes following at least 3 months tamoxifen.[42] Fifty-nine women were randomized to 15 sessions (5 weeks biweekly followed by 5 weeks weekly) real versus sham acupuncture. The authors measured mean number of hot flashes at baseline, at the end of the treatment period, and 12 weeks after treatment to assess the treatment effect. They reported that at the end of the treatment period, mean number of daytime hot flashes reduced significantly from 9.5 to 4.7 $(\mathrm{p}=0.001)$ in the real acupuncture arm, and from 12.3 to $11.7(\mathrm{p}=0.382)$ in the sham acupuncture arm. At 12 weeks follow up, further reduction was observed in real acupuncture arm (from 4.7 to 3.2) but not in sham acupuncture arm (from 11.7 to 12.1). A similar pattern was observed in night-time hot flashes as the number of hot flashes reduced from 6 to 2.6 in the real acupuncture arm and from 7.2 to 5.4 in the sham acupuncture arm at the end of the 
treatment period, with further reduction in the real acupuncture arm (from 2.6 to 1.7) but not sham acupuncture arm (from 5.4 to 6.1) at the 12 weeks follow up. The difference between the real and sham acupuncture arms was statistically significant $(\mathrm{p}<0.001)$. The authors concluded that acupuncture provided effective relief from hot flashes in breast cancer patients suffering from hot flashes while taking tamoxifen.[42] The evidence generated from these two trials suggests that acupuncture effectively decreases hot flashes frequency, although it is not clear whether it is superior to sham acupuncture.

In addition, another clinical trial compared the effects of electro-acupuncture (EA) with hormonal therapy in breast cancer survivors with vasomotor symptoms and showed that in the 19 out of 27 women who completed 12 weeks of EA treatment, the number of hot flashes significantly reduced from 9.6 per day to 4.3 per day. The improvement persisted at month 12 follow up.[43] In the hormonal treatment group, the median hot flashes number dropped from 6.6 at baseline to 0 at week 12. Although flushes decreased less in the EA group than in the HT group, HRQoL improved at least to the same extent. It suggests that EA should be further evaluated as treatment for women with breast cancer and climacteric complaints, since HT is no longer recommended for breast cancer survivors. [43]

Lastly, in 2010, Walker et al reported another RCT comparing the effect of acupuncture with venlafaxine in treating vasomotor symptoms in breast cancer patients suffering from greater than 13 hot flashes per week.[44] Changes in hot flash frequency from baseline to 3, 6, 9 and 12 month follow up were used as the primary outcome. Fifty patients were randomized to 12 weeks (biweekly for 4 weeks, followed by weekly for 8 weeks) of acupuncture versus daily venlafaxine (37.5mg for one week, then $75 \mathrm{mg}$ for 11 weeks). The investigators observed a significant reduction in hot flashes frequency and severity in both groups. In addition, two weeks after treatments were stopped, those randomized to venlafaxine reported increased in hot flash frequency, whereas the acupuncture group remained at low level of hot flashes. There was no significant difference between acupuncture arm and venlafaxine arm. There were 18 reported adverse events (i.e. nausea, dizziness, headache) in the venlafaxine arm and none in the acupuncture arm. The authors concluded that acupuncture appears as effective as venlafaxine and is a safe and durable treatment option for breast cancer patients experiencing vasomotor symptoms.[44]

A systematic review of six RCTs showed further research is needed to determine whether acupuncture produces specific effects that alleviate hot flashes in patients with breast cancer.[45] Lastly, hot flashes are also common side effects of hormonal therapy for prostate cancer patients. A pilot study showed that when 25 prostate cancer patients receiving androgen deprivation therapy (ADT) were treated with electroacupuncture biweekly for 4 weeks, then weekly for 6 weeks 9 out of 22 evaluable patients $(41 \%)$ had $>50 \%$ reduction in the hot flash score at week 4 , and 12 patients(55\%) had clinically significant reduction in hot flashes during the treatment course, and none had a significant increase in hot flashes during therapy.[46] This pilot study provided promising preliminary data to further study the role of acupuncture in treating hot flashes in prostate cancer patients. 


\section{Acupuncture to treat and prevent xerostomia}

Xerostomia, or dry mouth, is caused by the dysfunction of parotid glands damaged by radiation therapy and is considered a significant factor underlying dysphasia. Patients with xerostomia lose their taste and have difficulty speaking and swallowing. Several pilot clinical studies suggest that acupuncture may improve xerostomia symptoms caused by radiation therapy in patients who have head and neck cancers.[47-50] In addition, one clinical case series, seven xerostomia patients treated with acupuncture reported increase in salivary flow and ability to eat and speak.[51] Another study showed that after 12 session of acupuncture during 6 weeks, 12 patients with severe xerostomia had statistically significant improvement in salivary flow rates on both subjective and objective evaluations.[52]

Since then, a number of RCTs have been conducted to study the effect of acupuncture in treating and preventing radiation-induced xerostomia and are summarized in table 5. One study showed that even though both real and sham acupuncture increased the whole salivary flow rate with no significant difference between the two groups, it was only the real acupuncture that markedly increased the unstimulated salivary flow rates.[54] Moreover, real acupuncture significantly improved the dry mouth score when compared to sham acupuncture control.[54]

There has been a number of RCTs studying the effect of acupuncture in preventing xerostomia in head/neck patients undergoing radiotherapy. One study randomized 23 patients with nasopharygeal carcinoma to real acupuncture $(\mathrm{N}=11)$ and sham acupuncture $(\mathrm{N}=12)$ with three times/week treatment during radiation therapy. [55] Starting from week 3, xerostomia symptoms were significantly better in the real acupuncture group than sham acupuncture group, however, there was no significant difference in salivary flow rate. [55] The same group of investigators concurrently conducted another RCT that used standard care alone as control and showed that xerostomia symptoms was significantly better in the acupuncture group than standard care group starting in week 3 during radiation therapy through 6 months follow up. Interestingly, there was statistically significant greater saliva flow in the acupuncture group at week 7, 11 and 6 month follow up than in the standard care group. [56] Similar findings of acupuncture increased salivary flow when compared to standard care were reported in a smaller sample sized RCT.[57]

As exciting as these results were a recent systematic review on the preventive and therapeutic effect of acupuncture for radiation-Induced xerostomia in patients with head and neck cancer reported that because of the significant variation among the existing RCTs, metaanalysis was not possible. In the RCTs used placebo (sham acupuncture) control, no significant differences were noted between the two treatments with regard to increasing salivary flow. It was important to note that no significant side effects were reported due to acupuncture. The authors concluded that there was insufficient evidence available to judge if acupuncture is more effective than sham acupuncture in treating xerostomia and further research is needed.[58] 


\begin{tabular}{|c|c|c|c|c|}
\hline $\begin{array}{l}\text { Reference/ } \\
\text { Sample size }\end{array}$ & Treatment Groups & Treatment & Evaluation Method & Results \\
\hline \multicolumn{5}{|c|}{ Treatment Trials } \\
\hline $\begin{array}{c}\text { Blom et al } \\
1996[53] \\
N=38\end{array}$ & $\begin{array}{l}\text { 1.acupuncture } \\
\qquad(\mathrm{N}=20) \\
\text { 2.superficial } \\
\text { acupuncture } \\
(\mathrm{N}=18)\end{array}$ & $\begin{array}{c}\text { Twice per } \\
\text { week }\end{array}$ & salivary flow rates & $\begin{array}{c}\text { In both groups the patients showed } \\
\text { significantly increased salivary flow rates } \\
\text { after the acupuncture treatment. }\end{array}$ \\
\hline $\begin{array}{c}\text { Cho } \\
\text { et al. } \\
2008[54] \\
(\mathrm{N}=12)\end{array}$ & $\begin{array}{l}\text { 1.real acupuncture } \\
\qquad(\mathrm{N}=6) \\
\text { 2.sham } \\
\text { acupuncture }(\mathrm{N}=6)\end{array}$ & $\begin{array}{l}\text { twice weekly } \\
\text { for } 6 \text { weeks }\end{array}$ & $\begin{array}{l}\text { whole salivary flow } \\
\text { rates (stimulated and } \\
\text { unstimulated) and } \\
\text { questionnaire-based } \\
\text { assessment of } \\
\text { subjective symptoms }\end{array}$ & $\begin{array}{l}\text { Both groups showed a slight increase in } \\
\text { whole salivary flow rates, with no } \\
\text { significant difference between them. } \\
\text { However, real acupuncture markedly } \\
\text { increased unstimulated salivary flow } \\
\text { rates, and improved the score for dry } \\
\text { mouth according to the xerostomia } \\
\text { questionnaire, by } 2.33 \text { points versus } 0.33 \\
\text { in the controls. }\end{array}$ \\
\hline $\begin{array}{l}\text { Pfister et al } \\
2010[24] \\
N=58\end{array}$ & $\begin{array}{l}\text { 1.acupuncture } \\
\qquad(\mathrm{N}=28) \\
\text { 2. usual care } \\
(\mathrm{N}=30)\end{array}$ & $\begin{array}{c}\text { Once per } \\
\text { week }\end{array}$ & $\begin{array}{l}\text { Xerostomia Inventory } \\
\text { (although Xerostomia } \\
\text { was secondary end } \\
\text { point) }\end{array}$ & $\begin{array}{l}\text { Acupuncture produced greater } \\
\text { improvement in reported xerostomia } \\
\text { compared to usual care(adjusted } \\
\text { difference in Xerostomia Inventory = } \\
-5.8 ; 95 \% \mathrm{Cl},-0.9 \text { to }-10.7 ; \mathrm{P}=.02 \text { ). }\end{array}$ \\
\hline \multicolumn{5}{|c|}{ Prevention Trials } \\
\hline $\begin{array}{l}\text { Meng et al. } \\
\text { 2012[55] } \\
(\mathrm{N}=23)\end{array}$ & $\begin{array}{l}\text { 1.real acupuncture } \\
\qquad \begin{array}{l}(\mathrm{N}=11) \\
\text { 2.sham } \\
\text { acupuncture } \\
(\mathrm{N}=12)\end{array}\end{array}$ & $\begin{array}{l}\text { 3/week during } \\
\text { radiation } \\
\text { therapy }\end{array}$ & $\begin{array}{c}\text { Xerostomia } \\
\text { Questionnaire (XQ), MD } \\
\text { Anderson Symptom } \\
\text { Inventory for Head and } \\
\text { Neck Cancer (MDASI- }\end{array}$ & $\begin{array}{l}\text { XQ, MDASI-HN scores for acupuncture } \\
\text { were significantly lower than sham } \\
\text { controls starting in week } 3 \text { and lasted } \\
\text { through the 1-month follow-up. No } \\
\text { group differences for UWSFR and SSFR. }\end{array}$ \\
\hline $\begin{array}{l}\text { Meng et al. } \\
\text { 2012[56] } \\
(\mathrm{N}=86)\end{array}$ & $\begin{array}{l}\text { 1.acupuncture } \\
\qquad(\mathrm{N}=40) \\
\text { 2.standard care } \\
\quad(\mathrm{N}=46)\end{array}$ & $\begin{array}{c}\text { 3/week during } \\
\text { radiotherapy }\end{array}$ & $\begin{array}{l}\text { HN). Unstimulated } \\
\text { whole salivary flow } \\
\text { rates (UWSFR) and } \\
\text { stimulated salivary flow } \\
\quad \text { rates (SSFR). }\end{array}$ & $\begin{array}{l}\text { XQ, MDASI-HN scores for acupuncture } \\
\text { were significantly lower than standard } \\
\text { care control starting in week } 3 \text { and } \\
\text { lasted through the 6-month follow-up. } \\
\text { Greater saliva flow in the acupuncture } \\
\text { group at week 7, 11, 6-month follow-up } \\
\text { than standard care control. }\end{array}$ \\
\hline $\begin{array}{c}\text { Braga et al. } \\
\text { 2011[57] } \\
(\mathrm{N}=24)\end{array}$ & $\begin{array}{l}\text { 1. acupuncture } \\
\qquad(\mathrm{N}=12) \\
\text { 2. standard care } \\
(\mathrm{N}=12)\end{array}$ & $\begin{array}{l}\text { treated with } \\
\text { acupuncture } \\
\text { before and } \\
\text { during RT }\end{array}$ & $\begin{array}{l}\text { Syalometry, measuring } \\
\text { the resting (RSFR) and } \\
\text { stimulated (SSFR) } \\
\text { salivary flow rates, and } \\
\text { visual analogue scale } \\
\text { (VAS) regarding dry } \\
\text { mouth-related } \\
\text { symptoms }\end{array}$ & $\begin{array}{l}\text { Patients in the acupuncture group } \\
\text { showed improved salivary flow rates } \\
\text { (RSFR, SSFR; } p<0.001 \text { ) and decreased } \\
\text { xerostomia-related symptoms (VAS, } \mathrm{p}< \\
\text { 0.05) compared with patients in the } \\
\text { control group. }\end{array}$ \\
\hline
\end{tabular}

Table 5. Summary of Randomized Control Trials on Acupuncture for Xerostomia 


\section{Acupuncture to treat other cancer or cancer treatment-related symptoms}

\subsection{Depression and insomnia}

Acupuncture has been reported to reduce depression and improve sleep quality. There has not been extensive research conducted in this area. One recent RCT on 80 cancer patients suffering from cancer related depression and sleep disorder showed that acupuncture was more effective than fluoxetine in reducing depression and improving sleep quality.[59] Further study is warranted.

\subsection{Dysphagia}

Dysphagia is a common side effect from chemoradiation therapy (CRT) in patients with head and neck cancer (HNC). In a retrospective case series, 10 patients with HNC were treated with weekly acupuncture for radiation-induced dysphagia and xerostomia. Ninety percent patients reported subjective improvement and 86\% Percutaneous Endoscopic Gastrostomy (PEG)-tube dependent patients had their PEG-tube removed after acupuncture treatments.[60] The same group of researchers are conducting a randomized, sham acupuncture controlled clinical trial on 42 squamous cell carcinoma HNC patients to study the effect of acupuncture in treating dysphagia in HNC patients after chemoradiation.[61]

\subsection{Dyspnea}

Dyspnea is one of the most distressing symptoms experienced by end stage cancer patients. Pharmacologic management has proven yet limited benefit. Additional treatments are needed. Anecdotally, acupuncture has helped patients to breathe better. A pilot RCT on 47 lung and breast cancer patients, however, failed to show that.[62] Further study is needed.

\subsection{Lymphedema}

Lymphedema is a distressing symptom among cancer patients, especially breast cancer patients, with no effective treatment. There have been a number of observational studies showing the feasibility, safety and efficacy of acupuncture in reducing lymphedema in cancer patients.[63-66] Among them, one pilot study on 9 breast cancer patients with chronic lymphedema showed that 4 women had greater or equal to $30 \%$ reduction in the extent of lymphedema after 4 weeks biweekly acupuncture treatments. Importantly, no serious side effect from acupuncture was reported.[65]

\section{Discussion}

This chapter summarized the current practice and clinical research on acupuncture for cancer patients. It is important to note that with the use of acupuncture being more and more 
accepted by cancer patients and oncologists, there have been an increasing number of welldesigned clinical trials to support the practice. These trials have shown that there have been minimal side effects associated with acupuncture. When compared to standard care alone, acupuncture is superior in reducing both subjective and objective symptoms. However, when compared to placebo control (usually sham acupuncture), the benefit of acupuncture became less obvious. This may be due to the fact that sham acupuncture also has physiological effects. Indeed, one study already showed that both real and sham acupuncture significantly reduced patients' serum cortisol concentration.[67] Despite that the majority of RCTs showed no significant difference between real and sham acupuncture, acupuncture has been used more often by cancer patients in the clinical setting. This is mainly because of its minimal side effect and potential significant benefit. Further research needs to be conducted to study the mechanism of acupuncture and identify the population that may benefit most from acupuncture, and the conditions that acupuncture may be most helpful.

\section{Author details}

Lizhen Wang ${ }^{1,2}$ and Ting Bao ${ }^{2,3}$

1 Shanghai University of Traditional Chinese Medicine, College of Acupuncture-Moxibustion and Tuina, Shanghai, P.R. China

2 Center for Integrative Medicine, University of Maryland School of Medicine, Baltimore, Maryland, U.S.A.

3 The University of Maryland Marlene and Stewart Greenebaum Cancer Center, University of Maryland School of Medicine, Baltimore, Maryland, U.S.A.

\section{References}

[1] C T. Mechanism of acupuncture analgesia based on animal experiments. In: Pomerantz B SG, eds., ed. Scientific Bases of Acupuncture. Berlin, Germany: Springer-Verlag; 1989.

[2] Lee BY LP, Newberg AB. Acupuncture in theory and practice. Hospital Physician 2004;40:11-8.

[3] Cleeland CS, Gonin R, Hatfield AK, et al. Pain and its treatment in outpatients with metastatic cancer. N Engl J Med 1994;330:592-6.

[4] Brescia FJ, Portenoy RK, Ryan M, Krasnoff L, Gray G. Pain, opioid use, and survival in hospitalized patients with advanced cancer. J Clin Oncol 1992;10:149-55.

[5] Wells N. Pain intensity and pain interference in hospitalized patients with cancer. Oncol Nurs Forum 2000;27:985-91. 
[6] McMillan SC, Tittle M, Hagan S, Laughlin J. Management of pain and pain-related symptoms in hospitalized veterans with cancer. Cancer Nurs 2000;23:327-36.

[7] Foley K. Pain syndromes in patients with cancer. in Advances in Pain Research and Therapy. New York: Raven Press; 1979.

[8] Banning A, Sjogren P, Henriksen H. Pain causes in 200 patients referred to a multidisciplinary cancer pain clinic. Pain 1991;45:45-8.

[9] Coyle N, Adelhardt J, Foley KM, Portenoy RK. Character of terminal illness in the advanced cancer patient: pain and other symptoms during the last four weeks of life. J Pain Symptom Manage 1990;5:83-93.

[10] Zech DF, Grond S, Lynch J, Hertel D, Lehmann KA. Validation of World Health Organization Guidelines for cancer pain relief: a 10-year prospective study. Pain 1995;63:65-76.

[11] Lee H, Schmidt K, Ernst E. Acupuncture for the relief of cancer-related pain--a systematic review. Eur J Pain 2005;9:437-44.

[12] Choi TY, Lee MS, Kim TH, Zaslawski C, Ernst E. Acupuncture for the treatment of cancer pain: a systematic review of randomised clinical trials. Support Care Cancer 2012;20:1147-58.

[13] Paley CA, Johnson MI, Tashani OA, Bagnall AM. Acupuncture for cancer pain in adults. Cochrane Database Syst Rev 2011:CD007753.

[14] Hurlow A, Bennett MI, Robb KA, Johnson MI, Simpson KH, Oxberry SG. Transcutaneous electric nerve stimulation (TENS) for cancer pain in adults. Cochrane Database Syst Rev 2012;3:CD006276.

[15] Deng G, Rusch V, Vickers A, et al. Randomized controlled trial of a special acupuncture technique for pain after thoracotomy. J Thorac Cardiovasc Surg 2008;136:1464-9.

[16] Wong RH, Lee TW, Sihoe AD, et al. Analgesic effect of electroacupuncture in postthoracotomy pain: a prospective randomized trial. Ann Thorac Surg 2006;81:2031-6.

[17] Mehling WE, Jacobs B, Acree M, et al. Symptom management with massage and acupuncture in postoperative cancer patients: a randomized controlled trial. J Pain Symptom Manage 2007;33:258-66.

[18] Crew KD, Capodice JL, Greenlee H, et al. Pilot study of acupuncture for the treatment of joint symptoms related to adjuvant aromatase inhibitor therapy in postmenopausal breast cancer patients. J Cancer Surviv 2007;1:283-91.

[19] Alimi D, Rubino C, Pichard-Leandri E, Fermand-Brule S, Dubreuil-Lemaire ML, Hill C. Analgesic effect of auricular acupuncture for cancer pain: a randomized, blinded, controlled trial. J Clin Oncol 2003;21:4120-6.

[20] Alimi D, Rubino C, Leandri EP, Brule SF. Analgesic effects of auricular acupuncture for cancer pain. J Pain Symptom Manage 2000;19:81-2. 
[21] He JP, Friedrich M, Ertan AK, Muller K, Schmidt W. Pain-relief and movement improvement by acupuncture after ablation and axillary lymphadenectomy in patients with mammary cancer. Clin Exp Obstet Gynecol 1999;26:81-4.

[22] Dang W, Yang J. Clinical study on acupuncture treatment of stomach carcinoma pain. J Tradit Chin Med 1998;18:31-8.

[23] Li QS, Cao SH, Xie GM, et al. Combined traditional Chinese medicine and Western medicine. Relieving effects of Chinese herbs, ear-acupuncture and epidural morphine on postoperative pain in liver cancer. Chin Med J (Engl) 1994;107:289-94.

[24] Pfister DG, Cassileth BR, Deng GE, et al. Acupuncture for pain and dysfunction after neck dissection: results of a randomized controlled trial. J Clin Oncol 2010;28:2565-70.

[25] Minton O, Higginson IJ. Electroacupuncture as an adjunctive treatment to control neuropathic pain in patients with cancer. J Pain Symptom Manage 2007;33:115-7.

[26] Schroder S, Liepert J, Remppis A, Greten JH. Acupuncture treatment improves nerve conduction in peripheral neuropathy. Eur J Neurol 2007;14:276-81.

[27] Crew KD, Capodice JL, Greenlee H, et al. Randomized, blinded, sham-controlled trial of acupuncture for the management of aromatase inhibitor-associated joint symptoms in women with early-stage breast cancer. Journal of clinical oncology : official journal of the American Society of Clinical Oncology 2010;28:1154-60.

[28] Naeim A, Dy SM, Lorenz KA, Sanati H, Walling A, Asch SM. Evidence-based recommendations for cancer nausea and vomiting. J Clin Oncol 2008;26:3903-10.

[29] Hickok JT, Roscoe JA, Morrow GR, King DK, Atkins JN, Fitch TR. Nausea and emesis remain significant problems of chemotherapy despite prophylaxis with 5-hydroxytryptamine-3 antiemetics: a University of Rochester James P. Wilmot Cancer Center Community Clinical Oncology Program Study of 360 cancer patients treated in the community. Cancer 2003;97:2880-6.

[30] Hesketh PJ. Chemotherapy-induced nausea and vomiting. N Engl J Med 2008;358:2482-94.

[31] Ezzo J, Streitberger K, Schneider A. Cochrane systematic reviews examine P6 acupuncture-point stimulation for nausea and vomiting. J Altern Complement Med 2006;12:489-95.

[32] Ezzo JM, Richardson MA, Vickers A, et al. Acupuncture-point stimulation for chemotherapy-induced nausea or vomiting. Cochrane Database Syst Rev 2006:CD002285.

[33] Gardani G, Cerrone R, Biella C, et al. A progress study of 100 cancer patients treated by acupressure for chemotherapy-induced vomiting after failure with the pharmacological approach. Minerva Med 2007;98:665-8.

[34] Dibble SL, Luce J, Cooper BA, et al. Acupressure for chemotherapy-induced nausea and vomiting: a randomized clinical trial. Oncol Nurs Forum 2007;34:813-20. 
[35] Enblom A, Johnsson A, Hammar M, Onelov E, Steineck G, Borjeson S. Acupuncture compared with placebo acupuncture in radiotherapy-induced nausea--a randomized controlled study. Ann Oncol 2012;23:1353-61.

[36] Enblom A, Lekander M, Hammar M, et al. Getting the grip on nonspecific treatment effects: emesis in patients randomized to acupuncture or sham compared to patients receiving standard care. PLoS One 2011;6:e14766.

[37] Lao L, Zhang G, Wong RH, Carter AK, Wynn RL, Berman BM. The effect of electroacupuncture as an adjunct on cyclophosphamide-induced emesis in ferrets. Pharmacol Biochem Behav 2003;74:691-9.

[38] Molassiotis A, Sylt P, Diggins H. The management of cancer-related fatigue after chemotherapy with acupuncture and acupressure: a randomised controlled trial. Complement Ther Med 2007;15:228-37.

[39] Mao JJ, Styles T, Cheville A, Wolf J, Fernandes S, Farrar JT. Acupuncture for nonpalliative radiation therapy-related fatigue: feasibility study. J Soc Integr Oncol 2009;7:52-8.

[40] Deng G, Vickers A, Yeung S, et al. Randomized, controlled trial of acupuncture for the treatment of hot flashes in breast cancer patients. Journal of clinical oncology : official journal of the American Society of Clinical Oncology 2007;25:5584-90.

[41] Vincent A, Barton DL, Mandrekar JN, et al. Acupuncture for hot flashes: a randomized, sham-controlled clinical study. Menopause 2007;14:45-52.

[42] Hervik J, Mjaland O. Acupuncture for the treatment of hot flashes in breast cancer patients, a randomized, controlled trial. Breast Cancer Res Treat 2009;116:311-6.

[43] Frisk J, Carlhall S, Kallstrom AC, Lindh-Astrand L, Malmstrom A, Hammar M. Long-term follow-up of acupuncture and hormone therapy on hot flushes in women with breast cancer: a prospective, randomized, controlled multicenter trial. Climacteric 2008;11:166-74.

[44] Walker EM, Rodriguez AI, Kohn B, et al. Acupuncture versus venlafaxine for the management of vasomotor symptoms in patients with hormone receptor-positive breast cancer: a randomized controlled trial. Journal of clinical oncology : official journal of the American Society of Clinical Oncology 2010;28:634-40.

[45] Lee MS, Kim KH, Choi SM, Ernst E. Acupuncture for treating hot flashes in breast cancer patients: a systematic review. Breast Cancer Res Treat 2009;115:497-503.

[46] Beer TM, Benavides M, Emmons SL, et al. Acupuncture for hot flashes in patients with prostate cancer. Urology 2010;76:1182-8.

[47] Johnstone PA, Peng YP, May BC, Inouye WS, Niemtzow RC. Acupuncture for pilocarpine-resistant xerostomia following radiotherapy for head and neck malignancies. Int J Radiat Oncol Biol Phys 2001;50:353-7. 
[48] Johnstone PA, Niemtzow RC, Riffenburgh RH. Acupuncture for xerostomia: clinical update. Cancer 2002;94:1151-6.

[49] Simcock R, Fallowfield L, Jenkins V. Group acupuncture to relieve radiation induced xerostomia: a feasibility study. Acupunct Med 2009;27:109-13.

[50] Garcia MK, Chiang JS, Cohen L, et al. Acupuncture for radiation-induced xerostomia in patients with cancer: a pilot study. Head Neck 2009;31:1360-8.

[51] Morganstein WM. Acupuncture in the treatment of xerostomia: clinical report. Gen Dent 2005;53:223-6; quiz 7.

[52] Braga FP, Sugaya NN, Hirota SK, Weinfeld I, Magalhaes MH, Migliari DA. The effect of acupuncture on salivary flow rates in patients with radiation-induced xerostomia. Minerva Stomatol 2008;57:343-8.

[53] Blom M, Dawidson I, Fernberg JO, Johnson G, Angmar-Mansson B. Acupuncture treatment of patients with radiation-induced xerostomia. Eur J Cancer B Oral Oncol 1996;32B:182-90.

[54] Cho JH, Chung WK, Kang W, Choi SM, Cho CK, Son CG. Manual acupuncture improved quality of life in cancer patients with radiation-induced xerostomia. J Altern Complement Med 2008;14:523-6.

[55] Meng Z, Kay Garcia M, Hu C, et al. Sham-controlled, randomised, feasibility trial of acupuncture for prevention of radiation-induced xerostomia among patients with nasopharyngeal carcinoma. Eur J Cancer 2012;48:1692-9.

[56] Meng Z, Garcia MK, Hu C, et al. Randomized controlled trial of acupuncture for prevention of radiation-induced xerostomia among patients with nasopharyngeal carcinoma. Cancer 2012;118:3337-44.

[57] Braga FP, Lemos Junior CA, Alves FA, Migliari DA. Acupuncture for the prevention of radiation-induced xerostomia in patients with head and neck cancer. Braz Oral Res 2011;25:180-5.

[58] Zhuang L, Yang Z, Zeng X, et al. The Preventive and Therapeutic Effect of Acupuncture for Radiation-Induced Xerostomia in Patients With Head and Neck Cancer: A Systematic Review. Integr Cancer Ther 2012.

[59] Feng Y, Wang XY, Li SD, et al. Clinical research of acupuncture on malignant tumor patients for improving depression and sleep quality. J Tradit Chin Med 2011;31:199-202.

[60] Lu W, Posner MR, Wayne P, Rosenthal DS, Haddad RI. Acupuncture for dysphagia after chemoradiation therapy in head and neck cancer: a case series report. Integr Cancer Ther 2010;9:284-90.

[61] Lu W, Wayne PM, Davis RB, et al. Acupuncture for dysphagia after chemoradiation in head and neck cancer: rationale and design of a randomized, sham-controlled trial. Contemp Clin Trials 2012;33:700-11. 
[62] Vickers AJ, Feinstein MB, Deng GE, Cassileth BR. Acupuncture for dyspnea in advanced cancer: a randomized, placebo-controlled pilot trial [ISRCTN89462491]. BMC Palliat Care 2005;4:5.

[63] Kanakura Y, Niwa K, Kometani K, et al. Effectiveness of acupuncture and moxibustion treatment for lymphedema following intrapelvic lymph node dissection: a preliminary report. Am J Chin Med 2002;30:37-43.

[64] Yang XH, Liu H, Chai JH, Zhao XC. [Observation on 27 elderly women in britain with lymphedema syndrome treated by acupuncture combined with medicine]. Zhongguo Zhen Jiu 2009;29:998-1000.

[65] Cassileth BR, Van Zee KJ, Chan Y, et al. A safety and efficacy pilot study of acupuncture for the treatment of chronic lymphoedema. Acupunct Med 2011;29:170-2.

[66] de Valois BA, Young TE, Melsome E. Assessing the feasibility of using acupuncture and moxibustion to improve quality of life for cancer survivors with upper body lymphoedema. Eur J Oncol Nurs 2012;16:301-9.

[67] So EW, Ng EH, Wong YY, Yeung WS, Ho PC. Acupuncture for frozen-thawed embryo transfer cycles: a double-blind randomized controlled trial. Reprod Biomed Online 2010;20:814-21.

[68] Johnston MF, Hays RD, Subramanian SK, et al. Patient education integrated with acupuncture for relief of cancer-related fatigue randomized controlled feasibility study. BMC Complement Altern Med 2011;11:49.

[69] Balk J, Day R, Rosenzweig M, Beriwal S. Pilot, randomized, modified, double-blind, placebo-controlled trial of acupuncture for cancer-related fatigue. J Soc Integr Oncol 2009;7:4-11. 
